\title{
Small faecal pellets in Ordovician shelly fossils from Estonia, Baltoscandia
}

\author{
Ursula Toom $^{\mathrm{a}}$, Olev Vinn ${ }^{\mathrm{b}}$, Mare Isakar ${ }^{\mathrm{c}}$, Anna Madison ${ }^{\mathrm{d}}$ and Olle Hints ${ }^{\mathrm{a}}$ \\ a Department of Geology, School of Science, Tallinn University of Technology, Ehitajate tee 5, 19086 Tallinn, Estonia; \\ ursula.toom@taltech.ee, olle.hints@taltech.ee \\ b Institute of Ecology and Earth Sciences, University of Tartu, Ravila 14A, 50411 Tartu, Estonia; olev.vinn@ut.ee \\ c Geological collections of Natural History Museum, University of Tartu, Vanemuise 46, 51014 Tartu, Estonia; mare.isakar@ut.ee \\ d Borissiak Paleontological Institute, Russian Academy of Sciences, Profsoyuznaya ul. 123, Moscow, 117647 Russia; \\ Sunnyannmad@yahoo.com
}

Received 6 August 2019, accepted 23 October 2019, available online 19 December 2019

\begin{abstract}
Coprolites (fossil faeces) constitute a group of soft sediment trace fossils that provide useful palaeoecological and sedimentological information, but have generally low preservational potential. In this paper we report abundant occurrence and high diversity of small faecal pellets preserved inside different shelly fossils from Middle and Upper Ordovician carbonates of the Baltoscandian palaeobasin. The material contains ca 180 body fossils with faecal pellets from 40 localities, corresponding to a range of shallow-marine environments from cool-water carbonate ramp to tropical open shelf settings. Stratigraphically the finds range from the Volkhov to Pirgu regional stages (Dapingian to uppermost Katian). The pellets are elliptical or rod-shaped, 0.1-1.8 mm long and $0.08-0.75 \mathrm{~mm}$ in diameter, with the length/diameter ratio ranging from less than 2 to ca 6 . They occur in shells of gastropods, bivalves, cephalopods, brachiopods, echinoderms and trilobites and represent two ichnospecies, Coprulus oblongus and Coprulus bacilliformis, and some intermediate forms belonging to the same ichnogenus. Additionally, two compound traces were identified: Tubularina (pellets inside small burrows with circular cross section) and Alcyonidiopsis (pellets inside ribbon-shaped burrows). The pellets were produced when the empty shells were located on the seafloor, or possibly during shallow burial in the oxic zone. The preservation of faecal pellets is due to an interaction of several factors, notably protection by the shells and rapid mineralization. The origin of trace makers remains speculative, but polychaete worms having compatible size and body plan and living representatives who produce similar faecal pellets are among the most likely groups. Possibly organisms with different feeding strategies were involved in producing the faecal pellets. Systematic examination of shelly fossils from selected localities showed that up to about half of the shells may contain pellets, which indicates great abundance and diversity of pellet-producing organisms in the Ordovician Baltoscandian basin. Our material also shows that the trace maker of Arachnostega was not related to the faecal pellets inside the shells.
\end{abstract}

Key words: micro-coprolites, faecal pellets, Coprulus, Tubularina, Alcyonidiopsis, shallow-marine carbonates, Ordovician, Estonia.

\section{INTRODUCTION}

Trace fossils are important environmental indicators and provide valuable knowledge of animal behaviour in the geological past (Seilacher 2007). Trace-fossil assemblages of the Ordovician of the Baltica craton are comparatively well studied (e.g. Dronov et al. 2002; Mikuláš \& Dronov 2005; Knaust \& Dronov 2013; Hanken et al. 2016), but only limited studies deal with material from Estonia (Männil 1966b; Vinn et al. 2014, 2015; Vinn \& Toom 2016; Toom et al. 2019a, 2019b).
Coprolites (fossil faeces) represent a distinct category of trace fossils common since the early Palaeozoic different morphotypes are known already from the Cambrian (e.g. Vizcaïno et al. 2004; Eriksson \& Terfelt 2007; Shen et al. 2014; Kimming \& Strotz 2017; Mángano et al. 2019). The term 'pellet' denotes grains of faecal origin according to Flügel (2004); however, some authors have used it without reference to their origin. The term is frequently used for small invertebrate excrements of millimetre scale, with simple elliptical or rod-shaped form. Like all soft-bodied organisms, coprolites have generally a low preservation potential. Their findings from Palaeozoic

(C) 2019 Authors. This is an Open Access article distributed under the terms and conditions of the Creative Commons Attribution 4.0 International Licence (http://creativecommons.org/licenses/by/4.0). 
siliciclastic sediments are mostly related to deeper-water settings with high sedimentation rates and specific preservation conditions. The occurrence of pellets in carbonate sediments is commonly related to tropical shallow-marine environments (Folk \& Robles 1964; Shinn 1968; Wanless et al. 1981) and is widely reported from Mesozoic and Cenozoic strata. Rapid lithification has played an important role in their preservation in carbonates (Knaust et al. 2012). The majority of faecal pellet ichnotaxa in carbonates have characteristic inner structure and belong to the ichnofamily Favreinidae. Small faecal pellets with an ornamented outer surface are assigned to a number of different ichnogenera (e.g. Heer 1853; Elliott 1963; Gramann 1966; Gaździcki 1974; Gaillard 1978; Agarwal 1988; Živković \& Bogner 2006), whereas isolated faecal pellets without internal structure and ornamentation are representing the ichnofamily Coprulidae (Knaust 2008).

Faecal pellets are common in the Ordovician rocks of Europe (Häntzschel 1962; Benton \& Hiscock 1996). They were first mentioned from Bohemia by Barrande (1872) and are commonly related to the ichnogenus Tomaculum Groom, 1902 (e.g. Pickerill \& Forbes 1979; Eiserhardt et al. 2001 and references therein; Mikuláš \& Slavíčková 2001; Bruthansová \& Kraft 2003; Neto de Carvalho \& Farinha 2006; Podhalańska 2007; Martin et al. 2016; Neto de Carvalho et al. 2016; van Keulen \& Rhebergen 2017). Groom (1902) left open the question of the origin of small pellets, but later authors have suggested a faecal origin for these particles (e.g. Frič 1908; Gutiérrez-Marco 1984; Mikuláš 1991; Eiserhardt et al. 2001; Bruthansová \& Kraft 2003; Neto de Carvalho \& Farinha 2006).

Faecal pellets may be associated with other trace fossils (e.g. Fürsich 1974; Seilacher 2007; Knaust 2008), constitute composite traces (Gaillard et al. 1994) or fill shells of molluscs and other invertebrates (e.g. Mayer 1955, 1958; Zhang et al. 2007; Mángano et al. 2019). From the Ordovician, faecal pellets in burrows have been described as Syncoprulus (=Tomaculum) (Richter \& Richter 1939; Pickerill et al. 1987), Alcyonidiopsis (Chamberlain 1977; Pickerill 1980; Pickerill \& Narbonne 1995; Orr 1996; Uchman et al. 2005), in branching burrows as Quebecichnus (Hofmann 1972) and in burrows with segmented fill as Compaginatichnus (Pickerill 1989). Gutiérrez-Marco (1984) described a cylindrical elongated cluster filled with small pellets inside a gastropod as Cilindrotomaculum.

The reports of pellets inside Ordovician shelly fossils are few and mostly come from siliciclastic basins (GutiérrezMarco 1984; Mikuláš 1992; Bruthansová \& Kraft 2003). The occurrence of pellets in shells from carbonate settings has only been mentioned by Põlma (1982), more recently by Toom et al. (2017, 2019a, 2019b) and van Keulen \& Rhebergen (2017). All these papers refer to the material from the Baltic region.
The aim of this study is to report the abundance of small faecal pellets inside various shelly fossils in the Ordovician shallow-marine carbonates of the Baltoscandian basin, describe their morphology and discuss the taxonomic, sedimentological and palaeobiological aspects.

\section{GEOLOGICAL BACKGROUND}

During the Ordovician, the study area was part of a shallow sea, which covered the western part of the Baltica craton. This epicontinental sea, the Baltoscandian basin, extended from Norway to the Volga area in western Russia, and from the Fennoscandian mainland in the north to the Sarmatian mainland in the south (Fig. 1; Nestor \& Einasto 1997). The Ordovician outcrop area in northern Estonia, where most of the material of the present study derives from, was characterized by relatively shallowwater settings of the basin, whereas deeper shelf environments, the so-called Livonian basin, were located in the south (Fig. 1). Baltica drifted from high southern latitudes to the tropical area (Torsvik \& Cocks 2013 and references therein), causing a gradual change in climate and depositional conditions. In Estonia, carbonate sedimentation commenced at the end of the Floian (latest Early Ordovician) in a relatively cool, flat-bottomed epicontinental basin (Dronov \& Rozhnov 1997). In the Middle and early Late Ordovician, the basin was characterized by extremely low sedimentation rates and with little bathymetric differentiation (Jaanusson 1973). In the Late Ordovician, the climatic change resulted in an increase in carbonate production and sediment accumulation rates on the platform. The basin started to differentiate particularly in the early Katian (Nestor \& Einasto 1997). At that time the first tropical carbonate buildups appeared in the region (Kröger et al. 2017 and references therein).

The total thickness of the Ordovician succession in Estonia reaches about $180 \mathrm{~m}$ (Nõlvak 1997). The Ordovician carbonate rocks in Estonia are rich in shelly fossils such as brachiopods, bryozoans, cephalopods, gastropods, echinoderms, trilobites, corals, etc. Trace fossils are also common and diverse (Toom et al. 2019a) and the degree of bioturbation is generally high (Harris et al. 2004). A significant feature of Palaeozoic rocks of Estonia and the entire eastern Baltic region is a very low burial temperature indicated by conodont colour alteration index (CAI) values around 1 (Männik 2017).

The stratigraphic framework and time-correlations in the region are based on Baltic regional stages and highresolution biostratigraphy, notably trilobite, conodont, chitinozoan and graptolite zones (Nõlvak et al. 2006). We refer to both regional as well as global stages and series in the present study (Fig. 2). 


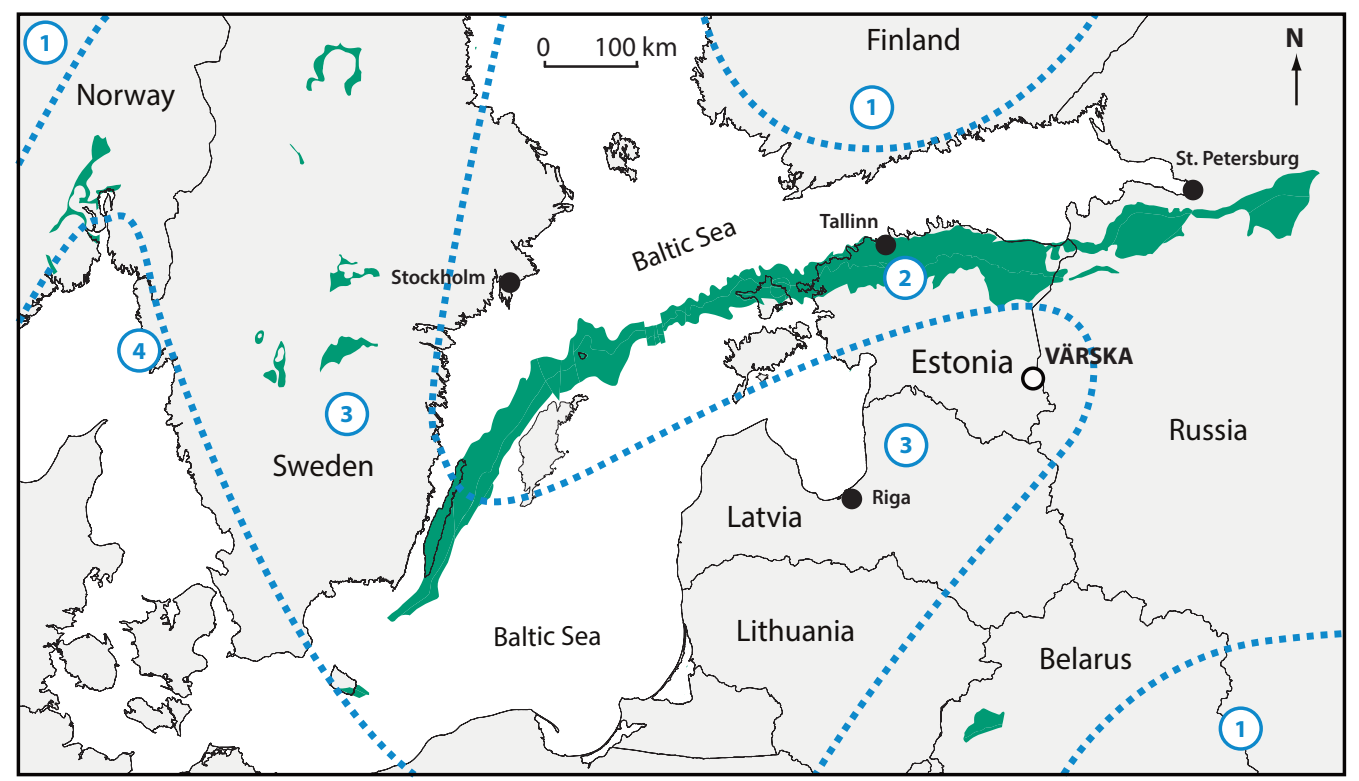

Fig. 1. Locality map showing the outcrop area of Ordovician rocks in the Baltic region (green) and schematic configuration of the Baltoscandian basin (after Männil 1966a and Nestor \& Einasto 1997). 1, main land areas; 2, shallow-water Estonian shelf; 3, deeperwater Livonian basin and Central Baltoscandian facies belt; 4, deep shelf of the Scanian facies belt (modified after Toom et al. 2019a).

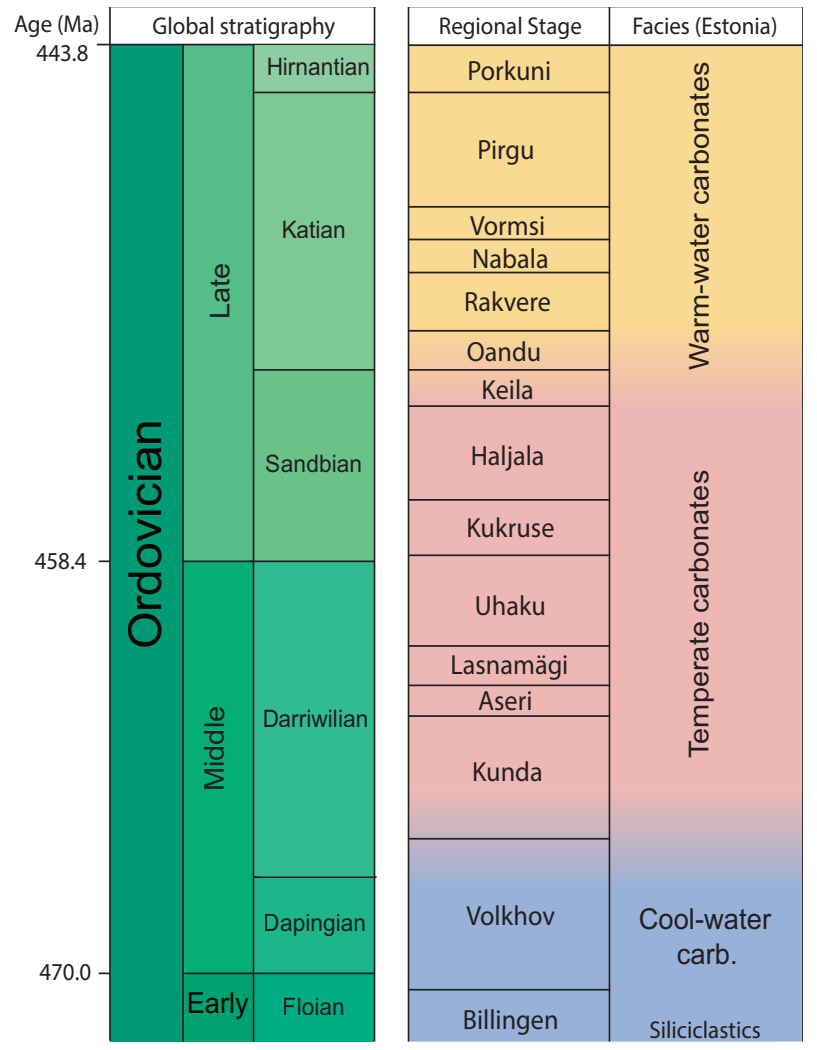

Fig. 2. Regional and international stratigraphy of the studied interval, showing transition from cool-water to warm-water carbonate deposits (modified after Toom et al. 2019a).

\section{MATERIAL AND METHODS}

Large palaeontological collections of Ordovician fossils from Estonia, housed at the Department of Geology, Tallinn University of Technology (indicated by the prefix GIT) and the Natural History Museum, University of Tartu (prefix TUG), were searched for shelly fossils containing small coprolites. In addition, the extensive lithological collection of eastern Baltic Ordovician rocks by Lembit Põlma (prefix GIT) was examined in order to reveal similar pellets dispersed in carbonate matrix.

The main method to identify the pellets was nondestructive observation of steinkerns, broken shelly fossils and rock samples already cut during previous studies. Better-preserved specimens were studied on steinkern surfaces only; the less valuable material was sectioned and polished for the determination and measurements of pellets. Only the specimens containing a large number of individual pellets on sectioned shells or steinkerns were used for measurements.

Additionally, a selection of shelly fossils from two localities were sectioned and examined in order to assess the relative abundance and distribution of pellet-filled shells. In this way, 30 gastropods and 30 brachiopods from the Aluvere quarry (Haljala Stage, Sandbian) and 30 gastropods from the Mõnuste quarry (Vormsi Stage, Katian) were studied.

Specimens were photographed with a Canon EOS 5DS R digital camera and a Leica Z16 APO zoom microscope system at the Department of Geology, 
Tallinn University of Technology. Measurements were taken from calibrated digital photos using Fiji image analysis software (https://imagej.net/Fiji). Selected specimens were additionally studied under a scanning electron microscope and analysed for chemical composition with EDS (TESCAN VEGA II XMU SEM with an X-Ray Energy Dispersive INCA ENERGY 450 microanalysis system at the A. A. Borissiak Paleontological Institute, Moscow). Data of individual specimens and related pellets (including images and localities) are deposited in the database of Estonian geocollections, which is accessible online at https://geocollections.info.

\section{RESULTS AND DISCUSSION}

\section{Characterization of faecal pellets and host shells}

Small pellets have been identified inside about 180 shelly fossils coming from 40 localities across the Ordovician outcrop area in Estonia and representing normal shallowmarine settings of the Estonian shelf (Table 1). So far only one specimen has been recovered from the deeper-shelf Livonian basin (Fig. 1). Stratigraphically the pellets in shells are known from the Volkhov (Dapingian) to Pirgu regional stages (Upper Katian); however, the majority comes from temperate and tropical carbonates (Table 1), with only a single record from cool-water limestone of the Volkhov Stage. The host rocks of shelly fossils with pellets are varied, ranging from wackestones and packstones to pure carbonate mudstones. Notably, so far, loose pellets have not been found from the host rocks.

Host shells containing faecal pellets belong to common Palaeozoic fossil groups: gastropods, bivalves, cephalopods, brachiopods, echinoderms and trilobites (Table 1). In general, the host dimensions range from ca 10 to $45 \mathrm{~mm}$; for cephalopods the diameter of the body chamber is less than $25 \mathrm{~mm}$. The size of pellets is very variable, ranging from 0.1 to $1.8 \mathrm{~mm}$ in length, and 0.08 to $0.5 \mathrm{~mm}$ in diameter. Within a single host shell, however, pellets are principally similar in their dimensions. The pellets are elongated, mostly elliptical or rod-shaped and always with circular cross section. Their length/diameter ratio is mostly less than 2 (Figs 3A, D, 4F-H, 5J, K) or 2-3 (Figs 3I, 4A, B, D, I, $5 \mathrm{C})$. Only few specimens show more elongated pellets, with the length/diameter ratio between 4 and 6 (Figs 3F, 5B). All pellets are devoid of the internal structure, and no constructional wall or lining has been observed. The EDS chemical analysis suggested a similar carbonate composition for pellets and rock matrix, while only a single specimen from the Haljala Stage (Sandbian) showed traces of silicification.
Pellets inside shells are organized in two different modes: the majority is represented by massive accumulations (Figs 3A-I, 4A-I, 5A-F), and in fewer cases (15 specimens), pellets are associated with small burrows (Fig. 5F-K). Massive accumulations consist of randomly oriented pellets which are not mixed with the sediment. The boundary between the sediment and pellets may be distinct (Fig. 3A) or transitional (Fig. 3G). The degree of preservation of pellets is variable, especially for the sets of massive accumulations. The decomposition process may affect an entire set (Fig. 3C) or only the periphery of an accumulation (Fig. 3G-I). The sediment inside the shells probably consists of decomposed pellets, especially if it does not contain bioclastic material. Some specimens contain pellets of two different sizes, located in separate sets (Figs 3E, 4I). The number of pellets in accumulations varies widely: for large pellets, less than hundred pieces make up an accumulation, but for the smallest pellets a set may contain more than a thousand pellets (Fig. 3A).

Sinuous, branching small burrows (diameter about 1$3 \mathrm{~mm}$, traceable length less than $10 \mathrm{~mm}$ ) may contain micritic, randomly oriented isolated elliptical pellets with the length/diameter ratio around 2 (Fig. 5F-J). Such pellets are well preserved, randomly oriented and loose. The burrows have sharp outline, circular cross section, which is mostly constant in diameter, and lack ornamentation or lining. In most cases the burrows with pellets are found within gastropods, but few are known inside brachiopods and bivalves. These burrows are oriented in different directions, but their total length and general configuration are difficult to establish as the pellets are mostly visible in cross section (Fig. 5G, H). A massive accumulation of pellets and burrows with pellets may occur together inside the same shell (Fig. 5I, J). However, the pellets inside the burrows are not coming from massive accumulations as they are different in size and preservation, and are thus likely made by the producers of the burrows. Additionally, a few trilobite specimens demonstrate specific ribbon-shaped, pelletfilled burrows with varying diameter (Fig. 5K).

The majority of pellet-filled fossils (a total of 112 specimens) are molluscs, especially gastropods (Figs 3E, FI, 4A-D, 5D, E, I, J). All common Ordovician gastropod genera are represented, but most finds are related to oblong and conical forms such as Subulites, Murchisonia, Hormotoma, Lophospira, Holopea, Liospira and Deaechospira. Fewer specimens come from depressed gastropod shells (the diameter is much larger than the height) like Pachystrophia, Lesueurilla, Cymbularia, Bucanella, Megalomphala and Salpingostoma. The gastropods vary in size, with the smallest measured specimen being $10.1 \mathrm{~mm}$ high and $16.4 \mathrm{~mm}$ wide, and the largest $102.1 \mathrm{~mm}$ high and $53.8 \mathrm{~mm}$ wide. Massive clusters of pellets are typically 


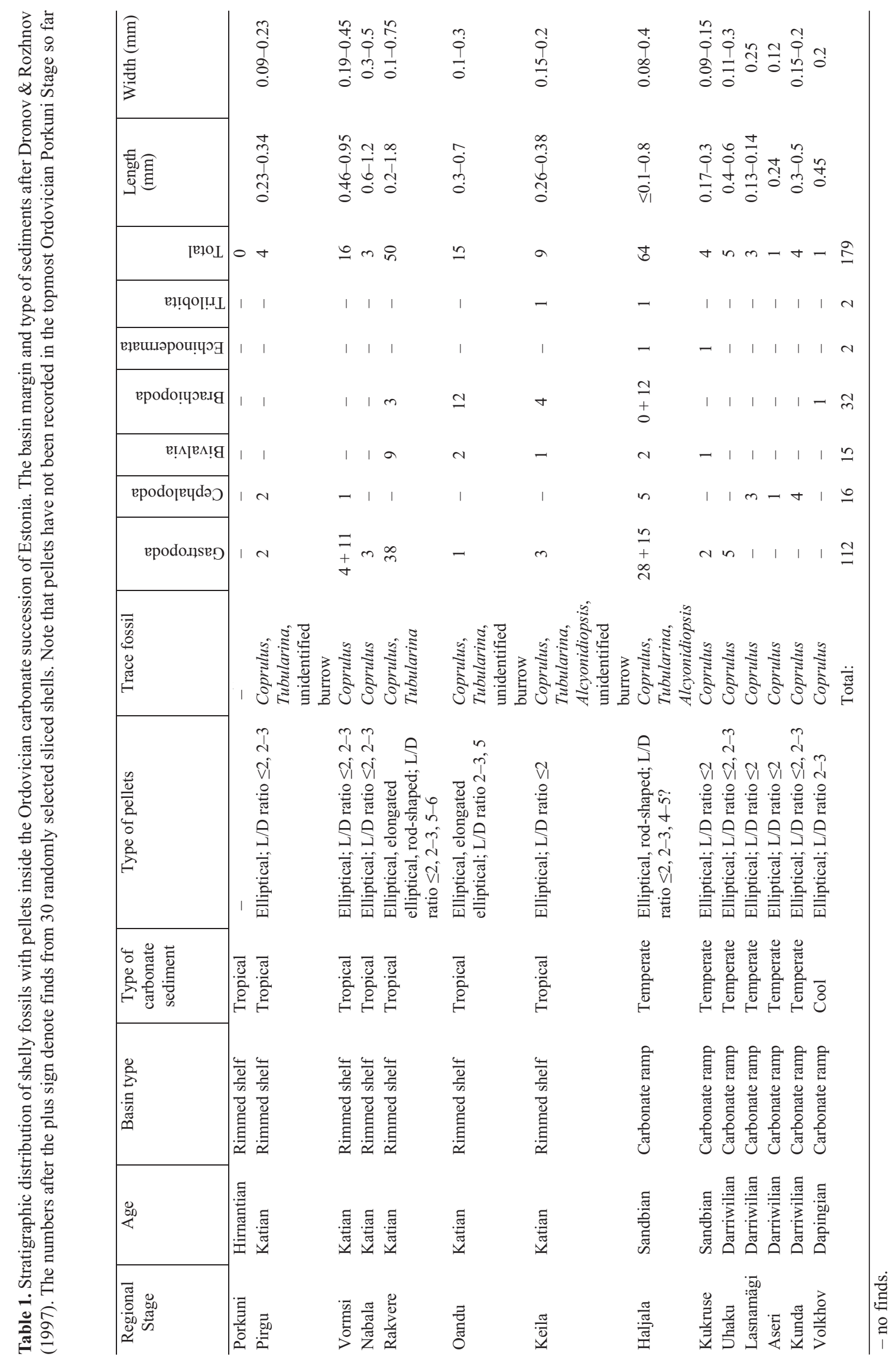




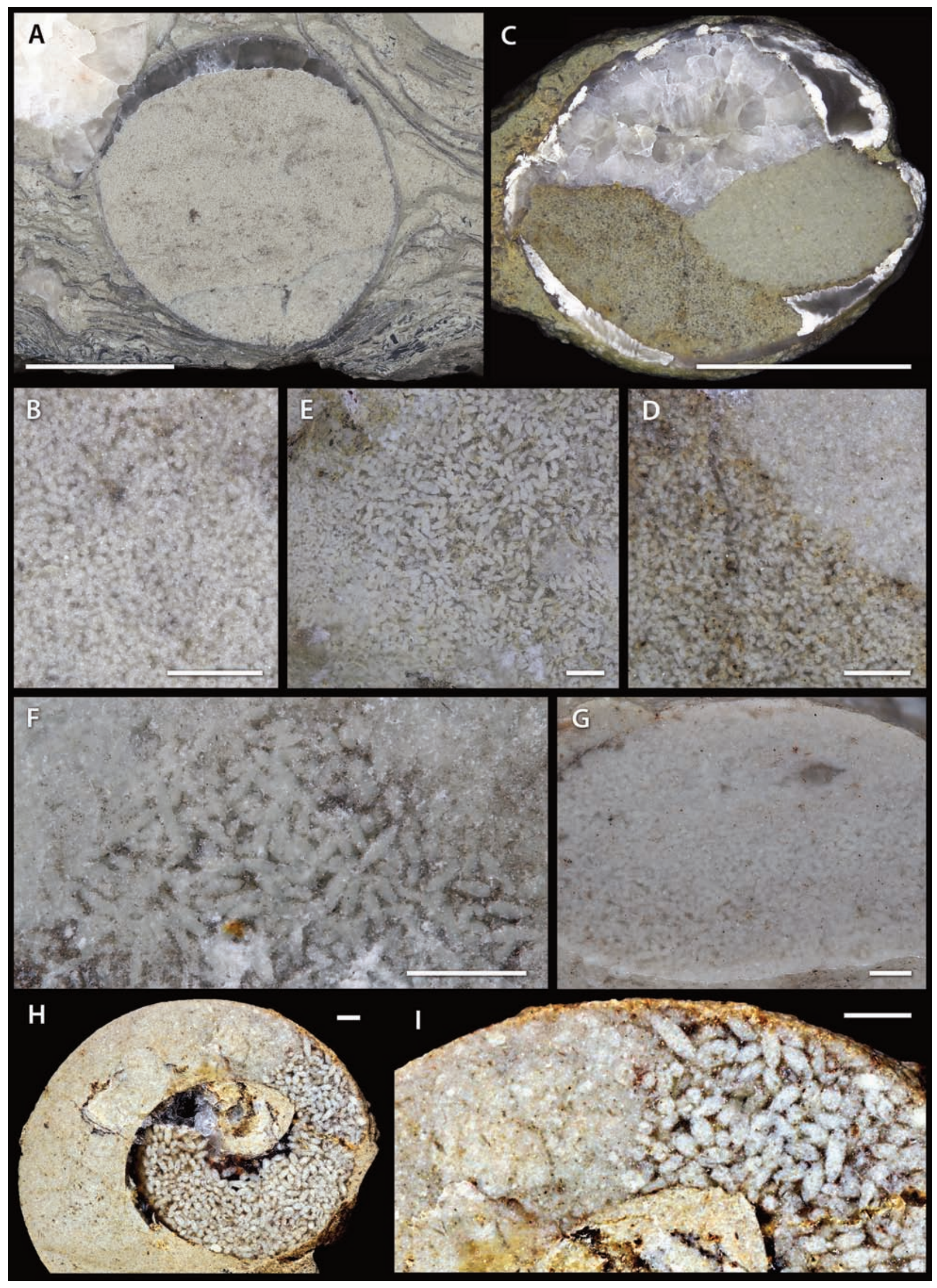


located in the apical parts of gastropod shells (Fig. 3H, I) For smaller shells, the entire whorl may be filled with pellets. In larger specimens, like Hormotoma insignis from the Rakvere Stage, the pellets may be accumulated in one side of the shell and the occurrence of pellets may be observed also in body whorl (Fig. 4C). Clusters, clusters together with burrows (Fig. 5I, J) and only burrows filled with pellets are observed in gastropod shells, however, the last case is rather exceptional. Stratigraphically the pellet-filled gastropods have been recorded from the Uhaku (late Darriwilian) to Pirgu stages (late Katian), with a higher number of finds from two levels: the Haljala (Sandbian) and Rakvere stages (Katian). The pellets inside gastropods show the highest variability in size and shape, including the largest pellets recovered during this study (Fig. 4A). Elliptical and rodshaped pellets with a length of $0.23-1.8 \mathrm{~mm}$, diameter $0.09-0.75 \mathrm{~mm}$ and various length/diameter ratios $(\leq 2,2-3$ and 4-5) are known. Notably, there is no correlation between the size of the shells and the size of the pellets they contain. The large open aperture of gastropods probably made them easy to inhabit and may have controlled the occurrence and variability of pellets. However, the higher variability of pellets in gastropod shells may also result from the largest number of specimens studied. The trace fossil Arachnostega is observed on the surface of some gastropod steinkerns (Fig. 4C, D).

Sixteen specimens of cephalopods contain pellets. Infills have been found in the body chamber, phragmocone between septae (Fig. 4E), as well as siphuncle (Fig. 4F). Frequently only one chamber between septae is filled (Fig. 4E) and bioturbation is common. Finds of pellets in cephalopods are mostly related to coiled and medium-size specimens with a diameter of aperture less than $25 \mathrm{~mm}$. Stratigraphically the occurrences range from the Kunda to Lasnamägi stages (Darriwilian), the Haljala Stage (Sandbian) and from the Vormsi to Nabala stages (Upper Katian). Most of the pellets are poorly preserved and relatively small in size (length $0.23-0.5 \mathrm{~mm}$, diameter $0.09-0.2 \mathrm{~mm}$ ), with the length/diameter ratio below 2 or 2-3. Most finds come from temperate-water carbonates, which may be the cause of a relatively small size of pellets in cephalopod shells. In addition, due to small holes in damaged phragmocones the shells could be inhabited by only small animals with a slender body plan. The small number of cephalopod specimens with pellets may be biased due to insufficient study, although, a recent thorough examination of a large number of lower Katian cephalopods by Kröger \& Aubrechtová (2018) did not reveal any finds with pellets.

Fifteen specimens of bivalves representing the genera Modiolopsis, Aristerella and Cypricardinia contain pellets (Fig. 5A-C, F-H). Shells with a length of 28-61 mm, height 16-44 mm and width 23-44 mm are partially filled with irregular clusters. Only the largest Cypricardinia contain several small burrows filled with pellets (Fig. 5F). Bivalves filled with pellets are recorded from the Kukruse to Rakvere stages (Sandbian to Katian). The pellets are elliptical (length $0.26-0.76 \mathrm{~mm}$, diameter $0.18-0.43 \mathrm{~mm}$ ), elongated elliptical (length $0.61 \mathrm{~mm}$, diameter $0.16 \mathrm{~mm}$ ) or rod-shaped (length $1.19 \mathrm{~mm}$, diameter $0.22 \mathrm{~mm}$ ), with the length/diameter ratio of $\leq 2,2-3$ or $4-6$. A relatively small number of finds exhibit surprisingly high variability of the shape of pellets. Few bivalve steinkerns show the presence of Arachnostega.

Thirty-two specimens of brachiopods contain pellets (examples in Figs 3C, D, 4G-I). Shell sections may be filled only with pellets (Fig. 3C), or more commonly, the irregular accumulations of pellets occur in some parts of the shell sections examined, like the spondylium (Fig. 4G). The smallest brachiopod with pellets is Platystrophia with a height of $9.4 \mathrm{~mm}$ and a width of $21.6 \mathrm{~mm}$, the largest is Porambonites wesenbergensis with a height of $45.4 \mathrm{~mm}$ and a width of $33.9 \mathrm{~mm}$. Bioturbation and multiple accumulations with different sizes of pellets are related to larger specimens (Fig. 4I). A single occurrence has been recorded from the Volkhov Stage, other finds come from the Haljala to Rakvere stages (Sandbian to Katian). Only elliptical pellets are observed, with a length of $0.2-1.1 \mathrm{~mm}$, diameter $0.1-$ $0.5 \mathrm{~mm}$ and the length/diameter ratio $\leq 2$ or $2-3$. Commonly large pellets occur inside large brachiopods, which may be related to the size of the pedicle opening. Few specimens of brachiopods also show the presence of Arachnostega.

Two echinoderm specimens belonging to Echinosphaerites and Sphaeronites contain irregular accumulations of small, elliptical pellets with a length of $0.1-0.4 \mathrm{~mm}$, diameter $0.08-0.24$ and the length/diameter

Fig. 3. Faecal pellets inside Ordovician shelly fossils from Estonia. Scale bars: $1 \mathrm{~cm}$ for A, C, H; $1 \mathrm{~mm}$ for B, E, D, F, G, I. A, echinoderm Sphaeronites, massive accumulation of pellets, vertical section, GIT 156-1066, Värska 6 drill core, 381.8 m, Haljala Stage, Sandbian. B, detail of GIT 156-1066, C. oblongus. C, brachiopod Porambonites, two sets of pellets inside, boundary between sets is distinct, one of the sets is almost completely decomposed, GIT 399-1961, Aluvere quarry, Haljala Stage, Sandbian. D, detail of GIT 399-1961, C. oblongus. E, gastropod Hormotoma insignis, surface of steinkern, two different sizes of Coprulus (L/W ratio 2.7), TUG 80-484, Piilse, Rakvere Stage, Katian. F, bivalve Aristerella, detail of surface, Coprulus (L/W ratio 4), GIT 694-93, Kullaaru ditch, Oandu Stage, Katian. G, gastropod Subulites wesenbergensis, horizontal section through the apical part of steinkern, boundary between the accumulation of pellets and sediment is transitional, decomposition of pellets is almost finished, GIT 404-639, Mõnuste quarry Harjumaa, Vormsi Stage, Katian. H, gastropod Lesueurilla, horizontal section through the apical part, Coprulus (L/W ratio 2.3), GIT 720-1, Aluvere quarry, Haljala Stage, Sandbian. I, detail of GIT 720-1, on the left side of the image are decomposed pellets. 





ratio below 2. The Sphaeronites shell is so far the only specimen characterizing the deeper shelf environments. It is noteworthy that the pellets it contains are the smallest among those recorded during the present study (Fig. 3A). The two specimens come from the Kukruse and Haljala stages (Sandbian).

Two trilobites have ribbon-shaped burrows on the dorsal surface of sediment infill of the cephalon of Oculichasmops and the pygidium of an asaphid trilobite (Fig. 5K). Stratigraphically the finds come from the Haljala and Keila stages (Sandbian and lower Katian). The pellets inside trilobites are elliptical in shape, with a length of $0.13-0.19 \mathrm{~mm}$, diameter $0.32-0.36 \mathrm{~mm}$ and the length/diameter ratio below 2 or $2-3$.

To some extent the data on pellet occurrences presented in Table 1 are biased by the different detection and study methods and the number of previous studies on different fossil groups. Pellets can rarely be observed on natural break surfaces due to the similar colour of pellets and matrix. However, the sectioning and polishing of surfaces reveals the pellets inside shells. The number of finds also depends on the degree of preservation of the shelly fossils. For instance, brachiopods have commonly well-preserved shells and pellet finds are related only to damaged specimens or material which was sectioned for other purposes. The prevalence of molluscs, and especially gastropods, can be explained by the conditions of 'calcite sea', where aragonitic shells dissolved rapidly (Palmer et al. 1988; Palmer \& Wilson 2004) and therefore the internal moulds with pellets became visible. Pellets were particularly well observable on the steinkerns of gastropods and bivalves derived from pure tropical limemudstones of the Rakvere and Nabala stages (Katian). These specimens were redeposited on the sediment surface before complete lithification of steinkerns but after the dissolution of shells. Steinkerns are deformed, with crush marks (Fig. 5D), containing small cracks (Fig. 5E), overgrown by trepostome bryozoans (Fig. 5D, E) and covered by pyrite threads (Fig. 5A). It can easily be identified on which side a gastropod or bivalve was lying on the sea floor after redeposition, as selective erosion by dissolution has made the pellets more distinct
(Fig. 5D, E). The dominance of gastropods among pellet substrates can also be explained by a more favourable microenvironment inside empty gastropod shells for pellet producers. An appropriate shape and size of shells may have contributed to better preservation. In addition, the open apertures of gastropod shells made them easily habitable, which is supported by a high variability in the size and shape of pellets.

The present collection is probably too small and taxonomically biased to fully assess the distribution of pellet-containing shells, including differences between fossil groups. However, the 90 randomly examined gastropod and brachiopod shells from two localities provide useful insights into these questions. Shelly fossils with pelletoidal infill were especially common in the Haljala and Rakvere stages (middle Sandbian and middle Katian; Table 1). Thirty random gastropods and 30 brachiopods from the fossil collection of the Aluvere quarry (Haljala Stage, Sandbian), without external indications of pellet occurrence, were sectioned and examined. The previous data from the same locality had shown high abundance of pellets inside gastropods and their absence inside brachiopods. From the selected 60 shells, 15 gastropods and 12 brachiopods yielded pellets, suggesting that nearly half of the shells contained pellets in both fossil groups. For comparison, 30 gastropods from the Mõnuste quarry (Vormsi Stage, upper Katian) were sectioned. Only few previous finds of shelly fossils with pellets were known from this stratigraphical interval. However, the study of 30 gastropod steinkerns revealed pellets in 11 cases, that is, in every third shell. This approach clearly shows that the pelletoidal infill is a very common phenomenon related to different shelly fossil groups and stratigraphical intervals within the Middle and Upper Ordovician carbonate succession of Estonia.

\section{Ichnogenus Coprulus - pellets in massive accumulations and inside burrows}

Richter \& Richter (1939) proposed the term Coprulus as an informal name. The formal ichnogenus Coprulus was erected by Mayer (1952) for isolated small pellets. Two

Fig. 4. Faecal pellets inside Ordovician shelly fossils from Estonia. Scale bars: $1 \mathrm{~mm}$ for A, B, D, F-I; $1 \mathrm{~cm}$ for C, E. A, gastropod Liospira wesenbergense, weathered steinkern, largest Coprulus (L/W ratio 2.5), TUG 1780-380, Rägavere quarry, Rakvere Stage, Katian. B, gastropod Hormotoma insignis, polished surface of steinkern, Coprulus (L/W ratio 2.4), TUG 76-63, Rägavere quarry, Rakvere Stage, Katian. C, gastropod Hormotoma insignis, steinkern surface with pellets and trace fossil Arachnostega, TUG 2-393, Rakvere, Rakvere Stage, Katian. D, detail of TUG 2-393, Coprulus (L/W ratio 3), Arachnostega and openings of small burrows filled with sparry calcite. E, section through the cephalopod phragmocone, only one chamber is filled with pellets, GIT 362-740, Viki drill core, 360.9 m, Kunda Stage, Darriwilian. F, section of cephalopod Estonioceras, detail from siphuncle filled with C. oblongus, GIT 146-7, Valkla outcrop, Kunda Stage, Darriwilian. G, section of brachiopod Clinambon anomalus, detail of spondylium filled with $C$. oblongus, GIT 543-1367, Saku 1098 drill core, 10.3 m, Keila Stage, Katian. H, brachiopod Porambonites, polished surface, C. oblongus (L/W ratio 2), GIT 619-85, Oandu River outcrops, Rakvere Stage, Katian. I, brachiopod Porambonites wesenbergensis, detail of sectioned surface, bioturbated pellets different in shape and size, TUG 1766-141, Oandu, Oandu Stage, Katian. 
ichnospecies, C. oblongus and C. sphaeroideus, were described and later $C$. bacilliformis was added (Mayer 1955). Knaust (2008) revised the diagnoses for the ichnogenus Coprulus and ichnospecies C. oblongus and brought out an important diagnostic feature for small pellets - the length/diameter ratio. Coprulus sphaeroideus

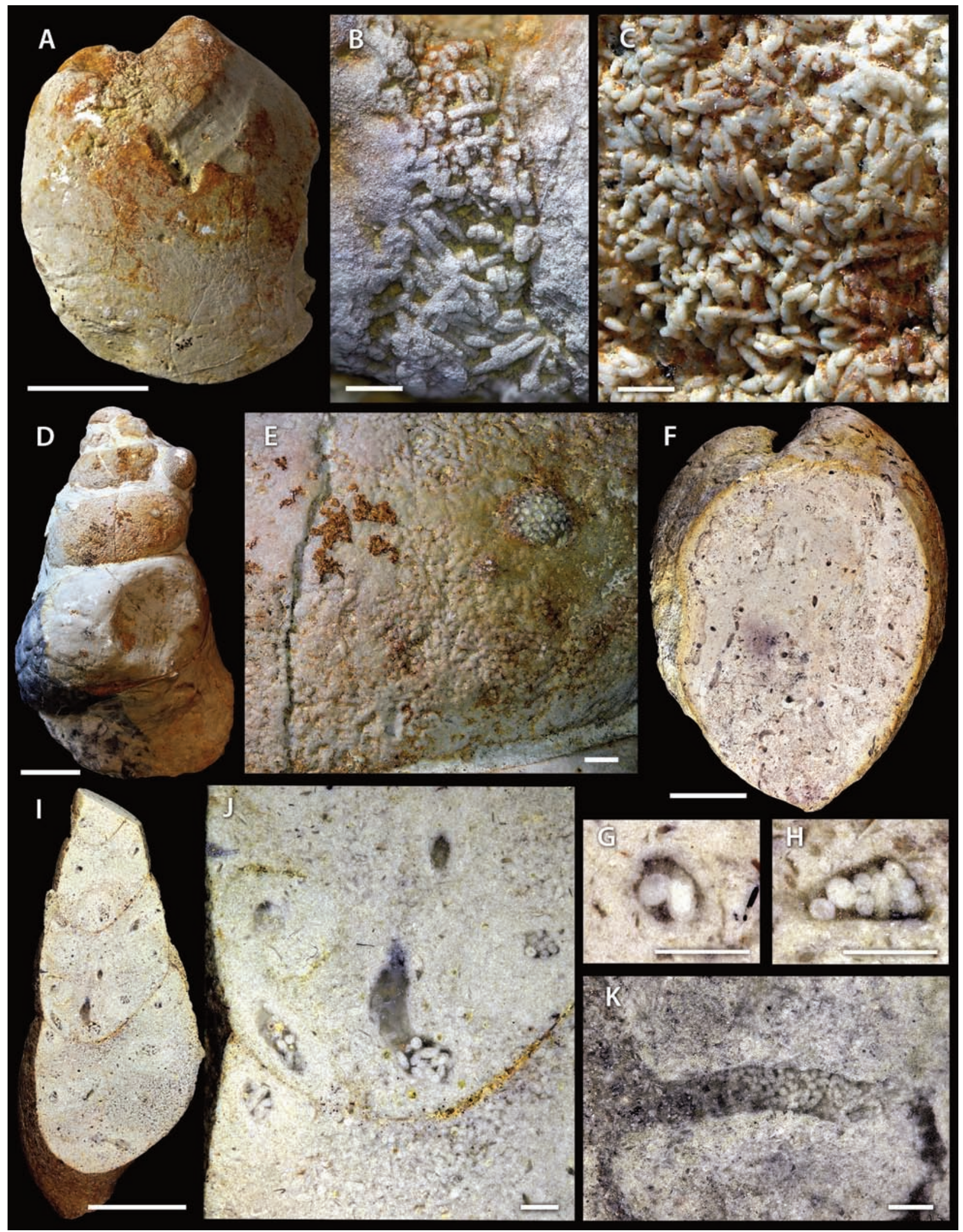


and the ichnogenus Tibiokia Hatai et al., 1970 were regarded as junior synonyms of $C$. oblongus; thus, the ichnogenus Coprulus includes two ichnospecies, $C$. oblongus and C. bacilliformis (Knaust 2008). The pellets of $C$. oblongus are isolated pills with a smooth surface, cylindrical to oval in shape and having a length/diameter ratio commonly between 1.5 and 2.0 (Knaust 2008). The pellets of $C$. bacilliformis have the length/diameter ratio around 6 and are rod-shaped (Mayer 1955).

It should be noted that diagnoses of $C$. oblongus by Mayer (1952) and Knaust (2008) are based on material where pellets are partly or completely washed in different burrows. According to Mayer (1952), C. oblongus has 'long-oval' shape, but Knaust (2008) refers to 'cylindrical to oval' shape. The pellets that were possibly washed in, instead of being formed in situ, may represent composite traces (structures made by combined activity of two or more species) and, according to Bertling et al. (2006), have no ichnotaxonomic standing. Arakawa (1970) introduced a detailed morphological classification of bivalve faeces. The faeces were divided into several types according to the structure and form. Three basic types were distinguished: oval, rod-shaped and ribbon-like pellets, and a large number of subtypes (pellet-types by Arakawa). According to Knaust (2008), C. oblongus includes pellets from oval to cylindrical shape, thus from two different basic types of Arakawa (1970). It has to be noted that for poorly preserved very small pellets with small length/diameter ratio values, differentiating between elliptical and rod-shaped forms may be complicated (see Fig. 3B).

Estonian faecal pellets in accumulations are mostly elliptical in shape, with the length/diameter ratio below 2 or 2-3 (Table 1). In few specimens with two different outlines, elliptical (Fig. 4F) and rod-shaped (Fig. 5B), this value is between 4 and 6 . Only half of shelly fossils in the Estonian material contained faecal pellets with an average length/diameter ratio around 2, and these can be confidently identified as C. oblongus. A small number of rod-shaped faecal pellets have the length/diameter ratio about 4-6, and these can be named as C. bacilliformis. However, a large number of pellets are elliptical with the length/diameter ratio over 2; these cannot be named at present without erecting a new species or emending the diagnoses of the existing species (Figs 3E, F, H, 4A, B,
D, 5C). Péneau (1941) described this type of pellets as Tomaculum. The Estonian material suggests that it is reasonable to include the elliptical pellets with the length/diameter ratio of $2-3$ in the ichnospecies $C$. oblongus. However, it is questionable that there is a good basis to assign the oblong elliptical pellets with length/diameter values over 4 to $C$. bacilliformis. As far as the original material of $C$. oblongus and $C$. bacilliformis described and figured by Mayer (1952, $1955)$ is not available for re-examination, we identify the elongated elliptical pellets with the length/diameter ratio over 2 only at the genus level.

\section{Compound trace Tubularina - pellets in small burrows}

Compound traces consist of combined individual traces with different morphologies that would be named differently if they were preserved in isolation (Miller 2003). Compound traces can only be named if all structures have been produced simultaneously (Bertling et al. 2006). For simple burrows filled with pellets, two compound trace-fossil genera Alcyonidiopsis Massalongo, 1856 and Tomaculum Groom, 1902 are most commonly identified and discussed from Palaeozoic strata. From Jurassic lagoonal limestones, Tubularina Gaillard et al. 1994, a small (diameter up to $2 \mathrm{~mm}$ ) firmground burrow filled with sparry calcite and loose pellets has been described. The walls of Tubularina are smooth, without ornamentation, and branching is observed. Tubularina is penetrating the sediment sinuously in very different directions. Burrows inside shelly fossils from the Haljala to Oandu stages (Sandbian and lower Katian) are very similar to the Jurassic material. Skeletal debris displaced concentrically around the burrows, and also the sharp contours and circular cross section of the burrow indicate that the traces were made into a coherent substrate.

\section{Ichnogenus Alcyonidiopsis - ribbon-shaped burrows with pellets inside trilobites}

Two specimens of trilobites from the Haljala and Keila stages contain curved ribbon-shaped burrows inside, filled with sparry calcite and pellets (Fig. 5K). No

Fig. 5. Faecal pellets inside Ordovician shelly fossils from Estonia. Scale bars: $1 \mathrm{~cm}$ for A, D, F, I; $1 \mathrm{~mm}$ for B, C, E, J, G, H, K. A, bivalve Modiolopsis, weathered steinkern covered by pyrite threads, TUG 1779-477, Rakvere, Rakvere Stage, Katian. B, detail of TUG 1779-477, rod-shaped pellets C. bacilliformis. C, bivalve Modiolopsis, detail of strongly weathered steinkern surface, Coprulus (L/W ratio 3), TUG 1779-439, Estonia, Rakvere Stage, Katian. D, gastropod Hormotoma insignis, redeposited steinkern with crush mark, cracks, overgrown by trepostome bryozoans, TUG 76-62, Rägavere quarry, Rakvere Stage, Katian. E, detail of TUG 76-62, steinkern surface with pellets and small bryozoan colony. F, bivalve Cypricardinia, vertical section, bioturbated sediments and composite trace fossil Tubularina, GIT 156-1079, Oandu, Keila Stage, Katian. G, H, detail of GIT 156-1079, Tubularina filled with C. oblongus, cross sections at different angles. I, gastropod Subulites amphora, vertical section, bioturbated accumulations of pellets and trace fossil Tubularina filled with C. oblongus, GIT 399-999, Aluvere quarry, Haljala Stage, Sandbian. J, detail of GIT 399999. K, pygidium of asaphid trilobite, Alcyonidiopsis filled with C. oblongus, GIT 362-726, Vasalemma quarry, Keila Stage, Katian. 
constructional wall or lining is observed; the boundary of the structure is marked by calcite. The burrows are located on the dorsal surface of the sediment infill, one on the cephalon and the other on the pygidium. The burrows are $1.7-2.9 \mathrm{~mm}$ and $1.1 \mathrm{~mm}$ wide, of somewhat variable width. The pellets are elliptical in shape and represent the ichnogenus Coprulus. These burrows are different from Tubularina, which has a circular cross section (Gaillard et al. 1994), and from Phymatoderma, which is a subhorizontally branching burrow system filled with pellets (Izumi 2012). The location of burrows on steinkerns is similar to that of Arachnostega, but the traces do not demonstrate the network characteristic of the latter; besides, the pelletoidal infill is unknown in Arachnostega. Bruthansová \& Kraft (2003) described pellets arranged in rows inside Ordovician trilobites as Tomaculum. However, a number of authors have considered that Alcyonidiopsis is the proper name for tubular burrows filled with faecal pellets (Chamberlain 1977; Pickerill 1980; Pickerill \& Narbonne 1995; Uchman 1995, 1999; Orr 1996; Uchman et al. 2005, 2013; Buatois at al. 2017; Mángano et al. 2019). Tomaculum consists of tightly packed pellets on bedding planes and is indicative of deep-water settings (e.g. Benton \& Trewin 1978; Zagora 1997; Podhalańska 2007). The trace is rare in Palaeozoic carbonates (Chamberlain 1977) but is also known from non-marine settings (Metz 2015). Mángano et al. (2019) described small burrows with pellets inside Cambrian bivalved arthropods as Alcyonidiopsis. The Estonian ribbon-shaped small burrows inside trilobites are most similar to Alcyonidiopsis. Additionally, a few shelly fossils with pellets inside demonstrate poorly preserved burrows with unclear shape and cross section (Table 1), which cannot be named at present.

\section{Notes on the preservation of pellets}

For all sectioned specimens, the taphonomic evidence suggests that the large accumulations of pellets were formed in situ, inside the shells. This is also proved by the specimens containing only pellets inside (Fig. 3C). Massive accumulations of pellets are not evenly mixed with the sediment, which also indicates that the pellets were not washed into the shells together with the sediment. Random placement of skeletal grains around the sets of pellets suggests that the sediment was not affected by the formation of pellets and proves that the pellets were not made in shells filled with sediment. In the case of shells with large apertures, like in gastropods, it is more likely that pellets were produced when the empty shell was lying on the sea floor and was afterwards filled with sediment. However, it is also possible that the dead body closed the aperture of the gastropods and pellets were formed when the shell was shallowly buried. More likely, shells with small openings, like brachiopods or echinoderms, could also be colonized by meiofauna and small macrofauna after shallow burial and the pellets were produced by infauna. According to Wilson \& Palmer (1992), the cementation is fastest just below the water-sediment interface. Rapid lithification is important for the formation and preservation of trace fossils in carbonates (Knaust et al. 2012). Eriksson et al. (2011) expressed the same opinion for the preservation of coprolites. Rapid lithification was likely favoured by small dimensions of the pellets examined in our study. Cementation by calcite resulting from aragonite dissolution may be confined to the areas immediately adjacent to dissolving bioclasts (Wilson \& Palmer 1992). This may be the explanation for the large number of finds related to the different mollusc shells.

In the Ordovician sediments of Estonia, pellets are found in cool-water to tropical carbonates (Table 1). Two stratigraphical levels, tropical carbonates of the Rakvere Stage (Katian) and temperate-water carbonates of the Haljala Stage (Sandbian), demonstrate a higher occurrence and better preservation of pellets. According to Flügel (2004), carbonate pellets can be preserved in warm-water environments with low energy and reduced sedimentation rates. The fossilization of the originally soft particles requires bacterial decomposition of organic mucus and intra-granular cementation by Mg-calcite. The higher number of findings and large scale in the shape and size of pellets are related to the Upper Ordovician, possibly due to the better preservation conditions in warm waters.

The increased number of shells with pellets in the Haljala Stage could be caused by the beginning of climate warming and supported by silicification of sediments. Extremely well-preserved pellets inside shelly fossils from Bohemia also showed a high degree of silicification (Bruthansová \& Kraft 2003). Tarhan et al. (2016) and Liu et al. (2019) have discussed rapid silicification for the preservation of soft-bodied fossils. Slightly silicified rocks have a wide distribution in Estonian shallow-water carbonate rocks, especially in the Haljala Stage. The source of silica is supposed to be organic, in particular siliceous sponges, and/or volcanic (Jürgenson 1958; Siir et al. 2015).

Environmental conditions, such as low oxygen levels in the sediment and/or fast burial, related to increase in sedimentation rates, may have contributed to the preservation of pellets. Anoxic conditions slowed down or stopped the decomposition of pellets. The processes occurring at the oxic/anoxic boundaries are controlled by the temperature, supply of organic matter, light, water currents and bioturbation (Kristensen 2000). The bioturbation inside a large number of steinkerns and on their surfaces indicates the existence of oxic environmental conditions inside the shells after the burial and before lithification. In addition, the activities of 
infaunal benthos stimulate microbial activity (Aller \& Aller 1982) and may in turn accelerate the decomposition of pellets. The physical mixing of sediments lowered the carbonate cementation (Wright \& Cherns 2016) and may have supported the degradation of pellets. The bestpreserved pellets were found inside the shells where bioturbation was not recorded. The tropical pure carbonates of the Rakvere Stage are, in general, characterized by a relatively low bioturbation rate and a small number of soft-sediment traces (Toom et al. 2019a).

High-energy environments with enhanced oxygen exposure are generally characterized by a very low burial efficiency of organic matter (Arndt et al. 2013). Microenvironment inside the shells was probably less affected, the oxygen diffusion into the sediment was decreased and the degradation of pellets was slowed down. The shells also shielded pellets and pellet-filled burrows with pellets from compaction and allowed an early cementation to occur as suggested by Mángano et al. (2019). This may explain the absence of pellets in the host rocks. However, water circulation in the uppermost sediment column favoured the lithification (Coimbra et al. 2009), and the shells may have acted as traps for calcium ions and promoted early cementation of small pellets. Supposedly, the microenvironment inside the protective shell was an important factor for the preservation of pellets in cool- and temperate-water environments of the Ordovician of Estonia.

Microbial communities are important in the decomposition of organic matter (Solan \& Wigham 2005; Morata \& Seuthe 2014). Microbes on pellets could originate from the water or sediment, or the gut of pellet producers being ingested with the food. The accumulations of fresh pellets, which contained less microorganisms, had a better preservation potential (Hargrave 1976). The decomposition process, which started from the outer edge of the set, did not reach the end of the set inside an elongated and narrow whorl (Fig. 3H). This may be the reason for a large number of finds of pellets in the apical parts of gastropod steinkerns. The organic matter may have played a major role in inhibiting precipitation of sedimentary carbonates (Morse et al. 2007).

In conclusion, it is difficult to identify one main reason for the observed preservation of pellets. Most likely it is due to the interaction of several factors including sea water and pore water chemistry, temperature, rapid lithification of small particles, favourable microenvironment inside the shells and the composition of pellets and microbial communities.

\section{The trace makers}

Flügel (2004) summarized a modern view on trace makers of small pellets: the assignment of pellets to specific pellet- producing animals is difficult because the pellets of most invertebrates lack specific morphological features. However, there are many publications dealing with excrements of different recent aquatic invertebrate groups (e.g. Moore 1931a, 1931b, 1939; Moore \& Kruse 1956; Manning \& Kumpf 1959; Kornicker 1962; Arakawa 1970, 1971; Kraeuter \& Haven 1970; Pryor 1975; Martens 1978; Ladle \& Griffiths 1980; Wotton \& Malmqvist 2001; Kulkarni \& Panchang 2015). In addition to detailed descriptions and classifications of pellets, a wide range of problems have been discussed. Moore (1939) concluded that in general carnivorous animals tend to produce faeces of loose consistency, and faeces of deposit feeders are the most resistant of all. Arakawa (1970) noted that variations in pellets are related to feeding habits and mode of life, and that the pellets of carnivores are very soft and irregular in shape. Excrements of loose consistency cannot be preserved as fossils (Kornicker 1962). The nature and form of faecal pellets are related to the structure and function of the digestive organs (Stamhuis et al. 1998). Unsculptured faecal rods are formed as mid-gut is very simple and circular (Arakawa 1970). The exact shape of pellets may vary; for instance, the excrements of a stressed or starved animal may be thinner and irregular in shape (Arakawa 1971).

Similar pellets inside different shells are described and discussed by Bruthansová \& Kraft (2003). These authors demonstrated that the pellets were not related to the animals that originally inhabited the shells. Our observations on the Ordovician material from Estonia confirm this conclusion - the pellets located on the ventral muscle scar of a brachiopod shell and in cephalopod phragmocone could not be produced by a brachiopod and cephalopod, respectively.

It is possible that some pellets were made by scavengers feeding on soft parts after the death of the animal with the shell (Bruthansová \& Kraft 2003) or on microbial halo formed around the decaying soft body. Deposit feeders appear to be limited largely to worms longer than $1 \mathrm{~cm}$. In general, juveniles and small worms are restricted to ingest highly digestible organic matter and rich food items (Jumars et al. 2015) and may be the trace makers, especially in the case of complete brachiopod shells, where a slender body shape was needed to enter the shell. Priapulids and arthropods, trilobites included, with mobile epifaunal lifestyle, are discussed as crayon feeders (Hu 2005). In addition, nematodes could feed on bacteria, fungi, algae and protozoans (Sun et al. 2014). Predators and scavengers have high assimilation efficiencies and produce small numbers of faecal pellets (Wotton \& Malmqvist 2001). The accumulations with a relatively small number of pellets (much less than 100 pellets per $\mathrm{cm}^{2}$ according to Wotton \& Malmqvist 2001) can be made by scavengers. However, in some cases the 
pellets were located in parts of the shell which did not contain a soft body, like between septae in the phragmocone. Other animals than scavengers should have been producing these clusters. Estonian pellets, composed of the same material as the host sediment, suggest that deposit feeders or suspension feeders were trace makers rather than predators and scavengers.

In shallow-marine environments, a cryptic environment inside shells provides shelter and food to different encrusters (Vinn et al. 2018). Our unpublished material of steinkerns brought up new data showing that the encrusting community is widespread and consists of different bryozoans, cornulitids and inarticulate brachiopods. It confirms that the empty shells provided suitable living environments in shallow-marine conditions. However, cooccurrence of pellets and different encrusters has not been observed. Considering the large number of pellets that the suspension feeders produce (Pryor 1975; Wotton \& Malmqvist 2001, and references therein), different cavities inside the shells were used as temporary hiding places rather than permanent domicle. Mobile trilobites used empty cephalopod shells for hiding (Davis et al. 2001). Bruthansová \& Kraft (2003) suggested that producers selected the shells according to their body dimensions. Our material supports this idea - pellets have not been observed inside the largest shells. In addition, the apertures/holes in shells that controlled the inhabiting community of shells were important.

García-Ramos et al. (2014) discussed a situation where pellets were stored to be used as a bacteriaenriched resource. Gardeners have low turbative activity, inhabiting relatively simple and almost permanent burrows with storage rooms (Stamhuis et al. 1998), and pellets may be stored inside the shells by gardeners. Invertebrates may live in a mixture of faecal pellets and fine particles (Levinton 2017).

Mayer $(1952,1958)$ originally interpreted Coprulus as faecal pellets of annelids. Recent excrements similar to Coprulus are commonly produced by polychaetes (Bałuk \& Radwański 1979; Gaillard et al. 1994; Knaust 2008; Kulkarni \& Panchang 2015). Kraeuter \& Haven (1970) investigated pellets of six modern shallow-marine phyla represented by 70 species and described thoroughly several characteristics. The elliptical or rod-like shape was common, but faecal pellets of polychaetes were of rod-like or ellipsoidal shape, with circular cross section, lacking sculpture and having mostly solid consistency. Various mud-dwelling and suspension-feeding polychaetes form solid and resistant pellets of very constant shape (Moore 1931b; Pryor 1975). Alcyonidiopsis and Tubularina, burrows actively filled with pellets, were interpreted as a feeding structure of polychaetes (Chamberlain 1977; Gaillard et al. 1994; Uchman et al. 2005; Mángano et al. 2019). Recently, palaeoscolecidans were discussed as potential trace makers (see Martin et al. 2016 and references therein). Based on evidence of scolecodonts, polychaetes were abundant and diverse in the Ordovician of Baltoscandia, especially starting from the Darriwilian (Hints 2000; Hints \& Eriksson 2007; Eriksson et al. 2013), and might have been responsible for various trace fossils, including the pellets reported herein. However, in ichnology the identity of trace makers mostly remains speculative. We may have the case of unknown feeding strategies and the animals that made the pellets may have no close living representatives.

Bruthansová \& Kraft (2003) described several Coprulus (as Tomaculum) specimens inside shells associated with Arachnostega-like traces. They suggested that pellets could be the faeces of the cryptic producers of Arachnostega which is a feeding trace inside the body fossils found at the contact of sediment filling and the inner surface of body fossils. Arachnostega is common also in the Ordovician of Estonia (Vinn et al. 2014). We recorded the co-occurrence of faecal pellets and Arachnostega in only few specimens, indicating that the trace maker of Arachnostega was probably not the producer of pellets inside the shells. Moreover, Arachnostega and Tubularina were made within coherent sediment, whereas faecal pellets were put into empty shells. Thus, the two traces could not be created simultaneously.

Bruthansová \& Kraft (2003) concluded that the producers of pellets inside shells come from different growth stages of a limited number of non-deposit-feeding taxa. The Estonian material inside shells is similar to the Bohemian pellets; they were made by trace makers with similar feeding strategies. Most likely filter feeders and scavengers looking for shelter were the producers of the pellets described herein. However, the large variation in size, shape and the number of pellets in accumulations and burrows suggest a wide spectrum of potential trace makers.

\section{CONCLUSIONS}

- Small faecal pellets are common inside shelly fossils (gastropods, bivalves, cephalopods, brachiopods, echinoderms and trilobites) in the Ordovician carbonate succession of Estonia. They may fill up half of the fossil shells.

- The faecal pellets are representing the ichnogenus Coprulus Mayer, 1952 and ichnospecies C. oblongus Mayer, 1952 sensu Knaust 2008, C. bacilliformis Mayer, 1955 and transitional unidentified forms.

- Compound traces consisting of small burrows with circular cross section and filled with faecal pellets inside various shelly fossils are representing the ichnogenus Tubularina Gaillard et al., 1994. Ribbonshaped burrows with faecal pellets inside trilobites are 
representing the ichnogenus Alcyonidiopsis Massalongo, 1856.

- Stratigraphically, faecal pellets occur in the Volkhov to Pirgu regional stages (Dapingian to upper Katian), thus they can be preserved in cool, temperate and warmwater shallow-marine conditions. The highest number of finds and largest morphological diversity, however, are encountered in the Upper Ordovician sediments.

- The size and shape of host shells control the occurrence of pellets in two ways: shells with large apertures were easier to inhabit by animals with different size and body plan, while in narrow and elongated shells, the process of decomposition was slowed down.

- The preservation of pellets has been due to interaction of several factors: chemical and physical processes that affect rapid lithification, factors that disturb mechanical and biological decomposition and the composition of pellets. In some cases, silicification may have supported the preservation of pellets in carbonates.

- Fauna inhabiting various empty shells was diverse through the Middle and Late Ordovician in Estonia. It consisted of mobile trace makers with different feeding strategies.

- The trace maker of Arachnostega was most probably not the producer of the faecal pellets inside shells.

Acknowledgements. We are grateful to the referees Dirk Knaust and Diego Kietzmann for their constructive comments that helped to improve the manuscript. We thank Dirk Knaust, Diego Kietzmann and Mike Reich for their help in acquiring research papers, Eberhard Schindler and Rainer Brocke for the fresh images of specimens from Péneau's collection, Toomas Post and Nordkalk for providing access to the Vasalemma quarry and Gennadi Baranov for excellent photographs of the specimens of faecal pellets. U. T. acknowledges support from the Doctoral School of Earth Sciences and Ecology (TalTech ASTRA development programme 20162022). Financial support to O. V. and O. H. was provided by the Estonian Research Council (grants IUT2034, PRG836). This paper is a contribution to the IGCP project 653 'The Onset of the Great Ordovician Biodiversification Event'. The publication costs of this article were partially covered by the Estonian Academy of Sciences.

\section{REFERENCES}

Agarwal, P. N. 1988. A record of Bactryllium Heer from the Lower Triassic Rocks at Khrew, Kashmir Himalaya. Journal of Geological Society of India, 31, 495-498.

Aller, R. \& Aller, J. 1982. The effect of biogenic irrigation intensity and solute exchange on diagenetic reaction rates in marine sediments. Journal of Marine Research, 56, 905-936.

Arakawa, K. Y. 1970. Scatological studies of the Bivalvia (Mollusca). Advances in Marine Biology, 8, 307-436.
Arakawa, K. Y. 1971. Studies on the faecal pellets of marine invertebrates (excluding molluscs). Publications of the Seto Marine Biological Laboratory, 19, 231-241.

Arndt, S., Jørgensen, B. B., LaRowe, D. E., Middelburg, J. J., Pancost, R. D. \& Regnier, P. 2013. Quantifying the degradation of organic matter in marine sediments: a review and synthesis. Earth-Science Reviews, 123, 53-86.

Bałuk, W. \& Radwański, A. 1979. Polychaete-attributable faecal pellets, Tibikoia sanctaecrucis ichnosp. n., from the Korytnica Clays (Middle Miocene; Holy Cross Mountains, Central Poland). Acta Geologica Polonica, 29, 339-344.

Barrande, J. 1872. Systême silurien du centre de la Bohème. Vol. I, Suppl. I. J. Barrande, Prague, 647 pp.

Benton, M. J. \& Hiscock, C. 1996. Lower Silurian trace fossils and the Eocoelia community in the Tortworth Inlier, SW England. Proceedings of the Geologists Association, 107, 199-208.

Benton, M. J. \& Trewin, N. H. 1978. Discussion and comments on Nicholson's 1872 manuscript 'Contributions to the study of the Errant Annelides of the older Palaeozoic rocks'. Publications of the Department of Geology and Mineralogy, University of Aberdeen, 1, 1-16.

Bertling, M., Braddy, S. J., Bromley, R. G., Demathieu, G. R., Genise, J., Mikuláš, R., Nielsen, J. K., Nielsen, K. S. S., Rindsberg, A. K., Schlirf, M. \& Uchman, A. 2006. Names for trace fossils: a uniform approach. Lethaia, 39, 265-286.

Bruthansová, J. \& Kraft, P. 2003. Pellets independent of or associated with Bohemian Ordovician body fossils. Acta Palaeontologica Polonica, 48, 437-445.

Buatois, L. A., Wisshak, M., Wilson, M. A. \& Mángano, M. G. 2017. Categories of architectural designs in trace fossils: a measure of ichnodisparity. Earth-Science Reviews, 164, 102-181.

Chamberlain, C. K. 1977. Ordovician and Devonian trace fossils from Nevada. Nevada Bureau of Mines and Geology, Bulletin, 90, 1-24.

Coimbra, R., Immenhauser, A. \& Olóriz, F. 2009. Matrix micrite $\delta^{13} \mathrm{C}$ and $\delta^{18} \mathrm{O}$ reveals synsedimentary marine lithification in Upper Jurassic Ammonitico Rosso limestones. Sedimentary Geology, 219, 332-348.

Davis, R. A., Fraye, R. H. B. \& Holland, C. H. 2001. Trilobites within nautiloid cephalopods. Lethaia, 34, 37-45.

Dronov, A. \& Rozhnov, S. 1997. Climatic changes in the Baltoscandian basin during the Ordovician: sedimentological and palaeontological aspects. Acta Geologica Sinica, 46, 108-113.

Dronov, A. V., Mikuláš, R. \& Logvinova, M. 2002. Trace fossils and ichnofabrics across the Volkhov depositional sequence (Ordovician, Arenigian of St. Petersburg Region, Russia). Journal of the Czech Geological Society, 47, 133-146.

Eiserhardt, K.-H., Koch, L. \& Eiserhardt, W. L. 2001. Revision des Ichnotaxon Tomaculum Groom, 1902. Neues Jahrbuch für Geologie und Paläontologie, Abhandlungen, 221, 325-358.

Elliott, G. F. 1963. Problematical microfossils from the Cretaceous and Palaeocene of the Middle East. Palaeontology, 6, 293-300.

Eriksson, M. E. \& Terfelt, F. 2007. Anomalous facies and ancient faeces in the latest middle Cambrian of Sweden. Lethaia, 40, 69-84.

Eriksson, M. E., Lindgren, J., Chin, K. \& Månsby, U. 2011. Coprolite morphotypes from the Upper Cretaceous of 
Sweden: novel views on an ancient ecosystem and implications for coprolite taphonomy. Lethaia, 44, 455468.

Eriksson, M. E., Hints, O., Paxton, H. \& Tonarová, P. 2013. Ordovician and Silurian polychaete diversity and biogeography. In Early Palaeozoic Biogeography and Palaeogeography (Harper, D. A. T. \& Servais, T., eds), Geological Society, London, Memoirs, 38, 265-272.

Flügel, E. 2004. Microfacies of Carbonate Rocks: Analysis, Interpretation and Application. Springer, Berlin, Heidelberg, 976 pp.

Folk, R. L. \& Robles, R. 1964. Carbonate sands of Isla Perez, Alacran Reef Complex, Yucatán. The Journal of Geology, 72, 255-292.

Frič, A. 1908. Problematica Silurica: Systême silurien du centre de la Bohême. A. Frič, Prague, 28 pp., 12 pls.

Fürsich, F. T. 1974. Corallian (Upper Jurassic) trace fossils from England and Normandy. Stuttgarter Beiträge zur Naturkunde, Serie B (Geologie und Paläontologie), 13, 152.

Gaillard, C. 1978. Révision de l'ichnogenere Coprulus Richter \& Richter, 1939, et description de quelques nouvelles espèces du Jurassique supérieur. Geobios, 11, 439-455.

Gaillard, C., Bernier, P., Gall, J. C., Gruet, Y., Barale, G., Bourseau, J. P., Buffetaut, E. \& Wenz, S. 1994. Ichnofabric from the Upper Jurassic lithographic limestone of Cerin, southeast France. Palaeontology, 37, 285-304.

Gaździcki, A. 1974. Rhaetian microfacies, stratigraphy and facial development in the Tatra Mts. Acta Geologica Polonica, 21, 387-397.

García-Ramos, J. C., Mángano, M. G., Piñuela, L. Buatois, L. A. \& Rodriguez-Tovar, F. J. 2014. The ichnogenus Tubotomaculum: an enigmatic pellet-filled structure from Upper Cretaceous to Miocene deep-marine deposits of southern Spain. Journal of Paleontology, 88, 1189-1198.

Gramann, F. 1966. Längsgeriefte Sediment-Stäbchen aus dem nordwestdeutschen Kimmeridge und ihre Deutung als Kotpillen mariner Invertebraten. Paläontologische Zeitschrift, 40, 262-268.

Groom, T. 1902. The sequence of the Cambrian and associated beds of the Malvern Hills. Quarterly Journal of the Geological Society of London, 58, 89-149.

Gutiérrez-Marco, J. C. 1984. Una interesante señal de actividad biológica en el Ordovícico de los Montes de Toledo. $C O L-P A, 39,17-25$.

Hanken, N.-M., Uchman, A., Nielsen, J. K., Olaussen, S., Eggebø, T. \& Steinsland, R. 2016. Late Ordovician trace fossils from offshore to shallow water mixed siliciclastic and carbonate facies in the Ringerike Area, Oslo Region, Norway. Ichnos, 23, 189-221.

Häntzschel, W. 1962. Trace fossils and problematica. In Treatise on Invertebrate Paleontology (Moore, R. C., ed.), pp. W177-245. Geological Society of America, New York and University of Kansas Press, Lawrence.

Hargrave, B. T. 1976. The central role of invertebrate faeces in sediment decomposition. In The Role of Terrestrial and Aquatic Organisms in Decomposition Processes (Anderson, J. M. \& Macfadyen, A., eds), pp. 301-321. Oxford, Blackwell.
Harris, M. T., Sheehan, P. M., Ainsaar, L., Hints, L., Männik, P., Nõlvak, J. \& Rubel, M. 2004. Upper Ordovician sequences of western Estonia. Palaeogeography, Palaeoclimatology, Palaeoecology, 210, 135-148.

Hatai, K. T., Kotaks, T. \& Noda, H. 1970. Supplementary note on the faecal pellets from the early Kogota Formation, KogotaMachi, Miyagi Prefecture, northeast Honshu, Japan. Saito Ho-on Kai Museum Research Bulletin, 39, 7-11.

Heer, O. 1853. Beschreibung der angeführten Pflanzen und Insekten. In Geologische Bemerkungen über das nördliche Vorarlberg und einige angrenzenden gegenden (Von Der Linth, E., ed.), Allgemeine Schweizer Gesellschaft für die gesamten Naturwissenschaften, Neue Denkschriften, Zürich, 13, 113-135.

Hints, O. 2000. Ordovician eunicid polychaetes of Estonia and surrounding areas: review of their distribution and diversification. Review of Palaeobotany and Palynology, $113,41-55$.

Hints, O. \& Eriksson, M. E. 2007. Diversification and biogeography of scolecodont-bearing polychaetes in the Ordovician. Palaeogeography, Palaeoclimatology, Palaeoecology, 254, 95-114.

Hofmann, H. J. 1972. Systematically branching burrows from the Lower Ordovician (Quebec Group) near Quebec, Canada. Paläontologische Zeitschrift, 46, 186-198.

$\mathrm{Hu}$, S. 2005. Taphonomy and palaeoecology of the Early Cambrian Chengjiang Biota from Eastern Yunnan, China. Berliner paläobiologische Abhandlungen, 7, 1-197.

Izumi, K. 2012. Formation process of the trace fossil Phymatoderma granulata in the Lower Jurassic black shale (Posidonia Shale, southern Germany) and its paleoecological implications. Palaeogeography, Palaeoclimatology, Palaeoecology, 353-355, 116-122.

Jaanusson, V. 1973. Aspects of carbonate sedimentation in the Ordovician of Baltoscandia. Lethaia, 6, 11-34.

Jumars, P. A., Dorgan, K. M. \& Lindsay, S. M. 2015. Diet of worms emended: an update of polychaete feeding guilds. The Annual Review of Marine Science, 7, 497-520.

Jürgenson, E. 1958. Forms of silica in Ordovician and Silurian carbonate rocks in Soviet Estonia. Eesti NSV Teaduste Akadeemia Geoloogia Instituudi Uurimused, 2, 87-92 [in Russian, with English summary].

Kimming, J. \& Strotz, L. C. 2017. Coprolites in mid-Cambrian (Series 2-3) Burgess Shale-type deposits of Nevada and Utah and their ecological implications. Bulletin of Geosciences, 92, 297-309.

Knaust, D. 2008. Balanoglossites Mägdefrau, 1932 from the Middle Triassic of Germany: part of a complex trace fossil probably produced by burrowing and boring polychaetes. Paläontologische Zeitschrift, 82, 347-372.

Knaust, D. \& Dronov, A. 2013. Balanoglossites ichnofabrics from the Middle Ordovician Volkhov formation (St. Petersburg Region, Russia). Stratigraphy and Geological Correlation, 21, 265-279.

Knaust, D., Curran, H. A. \& Dronov, A. V. 2012. Shallowmarine carbonates. In Trace Fossils as Indicators of Sedimentary Environments (Knaust, D. \& Bromley, R. D., eds), Developments in Sedimentology, 64, 705-750.

Kornicker, L. S. 1962. Evolutionary trends among mollusc fecal pellets. Journal of Paleontology, 36, 829-834. 
Kraeuter, J. \& Haven, D. S. 1970. Fecal pellets of common invertebrates of Lower York River and Lower Chesapeake Bay, Virginia. Chesapeake Science, 11, 159-173.

Kristensen, E. 2000. Organic matter diagenesis at the oxic/anoxic interface in coastal marine sediments, with emphasis on the role of burrowing animals. Hydrobiologia, 426, 1-24.

Kröger, B. \& Aubrechtová, M. 2018. Cephalopods from reef limestone of the Vasalemma Formation, northern Estonia (latest Sandbian, Upper Ordovician) and the establishment of a local warm-water fauna. Journal of Systematic Palaeontology, 16, 799-839.

Kröger, B., Hints, L. \& Lehnert, O. 2017. Ordovician reef and mound evolution: the Baltoscandian picture. Geological Magazine, 154, 683-706.

Kulkarni, K. G. \& Panchang, R. 2015. New insights into polychaete traces and fecal pellets: another complex ichnotaxon? PLoS One, 10, 1-10.

Ladle, M. \& Griffiths, B. S. 1980. A study on the feces of some chalk stream invertebrates. Hydrobiologia, 74, 161-171.

Levinton, J. S. 2017. Marine Biology: Function, Biodiversity, Ecology. Fifth Edition. Oxford University Press, New York, $530 \mathrm{pp}$.

Liu, A. G., McMahon, S., Matthews, J. J., Still, J. W. \& Brasier, A. T. 2019. Petrological evidence supports the death mask model for the preservation of Ediacaran soft-bodied organisms in South Australia. Geology, 47, 215-218.

Mángano, M. G., Hawkes, C. D. \& Caron, J.-B. 2019. Trace fossils associated with Burgess Shale non-biomineralized carapaces: bringing taphonomic and ecological controls into focus. Royal Society Open Science, 6, 172074.

Männik, P. 2017. Conodont biostratigraphy of the Oandu Stage (Katian, Upper Ordovician) in NE Estonia. Estonian Journal of Earth Sciences, 66, 1-12.

Männil, R. M. 1966a. Evolution of the Baltic Basin During the Ordovician. Valgus, Tallinn, 200 pp. [in Russian, with English summary].

Männil, R. M. 1966b. O vertikal'nykh norkakh zaryvaniya v ordovikskikh izvestnyakakh Pribaltiki [On vertical burrows in the Ordovician limestones of Baltic]. In Organizm i sreda $v$ geologicheskom proshlom [Organism and Environment in the Geological Past] (Gekker, R. F., ed.), pp. 200-207. Akademiya Nauk SSSR, Paleontologicheskij Institut, Nauka, Moskva [in Russian].

Manning, R. B. \& Kumpf, H. E. 1959. Preliminary investigations of the fecal pellets of certain invertebrates of the south Florida area. Bulletin of Marine Science Gulf and Caribbean, 9, 291-309.

Martens, P. 1978. Faecal pellets. Fiches D'Identification $d u$ zooplancton, 162, 1-4.

Martin, E., Lerosey-Aubril, R. \& Vannier, J. 2016. Palaeoscolecid worms from the Lower Ordovician Fezouata Lagerstatte, Morocco: palaeoecological and palaeogeographical implications. Palaeogeography, Palaeoclimatology, Palaeoecology, 460, 130-141.

Massalongo, A. B. 1856. Studii Paleontologici. Antonelli G., Verona. $53 \mathrm{pp}$.

Mayer, G. 1952. Neue Lebensspuren aus dem Unteren Hauptmuschelkalk (Trochitenkalk) von Wiesloch: Coprulus oblongus n. sp. und C. sphaeroideus n. sp. Neues
Jahrbuch für Geologie und Paläontologie, Monatshefte, 1952, 376-379.

Mayer, G. 1955. Kotpillen als Füllmasse in Hoernesien und weitere Kotpillenvorkommen im Kraichgauer Hauptmuschelkalk. Neues Jahrbuch für Geologie und Paläontologie, Monatshefte, 1955, 531-535.

Mayer, G. 1958. Rhizocorallien mit Wandkörperchen. Der Aufschlu $\beta, 8,314-316$.

Metz, R. 2015. First report of the ichnofossil Alcyonidiopsis Massalongo from New Jersey: second non-marine recording. Northeastern Geoscience, 33, 12-15.

Mikuláš, R. 1991. Trace fossils from siliceous concretions in the Šárka and Dobrotivá Formations (Ordovician, central Bohemia). Časopis pro mineralogii a geologii, 36, 2938.

Mikuláš, R. 1992. Trace fossils from the Kosov Formation of the Bohemian Upper Ordovician. Sbornik geologických věd, Geologie, 32, 9-54.

Mikuláš, R. \& Slavíčková, J. 2001. Trilobites and minute ovoid pellets in a burrow (Ordovician, Llanvirnian, Czech Republic). Ichnos, 8, 243-249.

Mikulás, R. \& Dronov, A. V. 2005 Trace fossils. In The Sixth Baltic Stratigraphical Conference. Cambrian and Ordovician of St. Petersburg Region, Guidebook for the Pre-conference Field Trip (Dronov, A. V., Tolmacheva, T. \& Raevskaya, E., eds), pp. 33-38. Saint Petersburg.

Miller, W. 2003. Paleobiology of complex trace fossils. Palaeogeography, Palaeoclimatology, Palaeoecology, 192, 3-14.

Moore, H. B. 1931a. The systematic value of a study of molluscan faeces. Proceedings of the Malacological Society of London, 19, 281-290.

Moore, H. B. 1931b. The specific identification of faecal pellets. Journal of the Marine Biological Association of the United Kingdom, 17, 359-369.

Moore, H. B. 1939. Faecal pellets in relation to marine deposits. In Recent Marine Sediments (Trask, P. D., ed.), pp. 516524. The American Association of Petroleum Geologists, Tulsa, Oklahoma.

Moore, H. B. \& Kruse, P. 1956. A Review of Present Knowledge of Faecal Pellets. University of Miami Institute of Marine Science, Marine Lab. Rept., No. 13805, 25 pp.

Morata, N. \& Seuthe, L. 2014. Importance of bacteria and protozooplankton for faecal pellet degradation. Oceanologia, 56, 565-581.

Morse, J. W., Arvidson, R. S. \& Luettge, A. 2007. Calcium carbonate formation and dissolution. Chemical Reviews, 107, 342-381.

Nestor, H. \& Einasto, R. 1997. Ordovician and Silurian carbonate sedimentation basin. In Geology and Mineral Resources of Estonia (Raukas, A. \& Teedumäe, A., eds), pp. 192-204. Estonian Academy Publishers, Tallinn.

Neto de Carvalho, C. \& Farinha, C. 2006. Coprolites from Portugal: a synthesis with the report of new findings. Ichnology Newsletter, 27, 10-15.

Neto de Carvalho, C., Couto, H., Figueiredo, M. V. \& Baucon, A. 2016. Microbial-related biogenic structures from the Middle Ordovician slates of Canelas (northern Portugal). Comunicações Geológica, 103(Especial 1), 23-38. 
Nõlvak, J. 1997. Ordovician, Introduction. In Geology and Mineral Resources of Estonia (Raukas, A. \& Teedumäe, A., eds), pp. 52-55. Estonian Academy Publishers, Tallinn.

Nõlvak, J., Hints, O. \& Männik, P. 2006. Ordovician timescale in Estonia: recent developments. Proceedings of the Estonian Academy of Sciences, Geology, 55, 95-108.

Orr, P. J. 1996. The ichnofauna of the Skiddaw Group (early Ordovician) of the Lake District, England. Geological Magazine, 133, 193-216.

Palmer, T. J. \& Wilson, M. A. 2004. Calcite precipitation and dissolution of biogenic aragonite in shallow Ordovician calcite seas. Lethaia, 37, 417-427.

Palmer, T. J., Hudson, J. D. \& Wilson, M. A. 1988. Palaeoecological evidence for early aragonite dissolution in ancient calcite seas. Nature, 335, 809-810.

Péneau, J. 1941. Die Anwesenheit von Tomaculum problematicum im Ordoviciums West-Frankreichs. Senckenbergiana, 23, 127-132.

Pickerill, R. K. 1980. Phanerozoic flysch trace fossil diversity observations based on an Ordovician ichnofauna from the Aroostook-Matapedia Carbonate Belt of northern New Brunswick. Canadian Journal of Earth Sciences, 17, 1259-1270.

Pickerill, R. K. 1989. Compaginatichnus: a new ichnogenus from Ordovician flysch of eastern Canada. Journal of Paleontology, 63, 913-919.

Pickerill, R. K. \& Forbes, W. H. 1979. Ichnology of the Trenton Group in the Quebec City area. Canadian Journal of Earth Sciences, 16, 2022-2039.

Pickerill, R. K. \& Narbonne, G. M. 1995. Composite and compound ichnotaxa: a case example from the Ordovician of Quebec, eastern Canada. Ichnos, 4, 53-69.

Pickerill, R. K., Fyffe, L. R. \& Forbes, W. H. 1987. Late Ordovician-Early Silurian trace fossils from the Matapedia Group, Tobique River, Western New Brunswick, Canada. Maritime Sediments and Atlantic Geology, 23, 77-88.

Podhalańska, T. 2007. Ichnofossils from the Ordovician mudrocks of the Pomeranian part of the TeisseyreTornquist Zone (NW Poland). Palaeogeography, Palaeoclimatology, Palaeoecology, 245, 295-305.

Põlma, L. 1982. Comparative Lithology of Ordovician Carbonate Rocks in North and Central East Baltic. Valgus, Tallinn, 152 pp. [in Russian, with English summary].

Pryor, W. A. 1975. Biogenic sedimentation and alteration of argillaceous sediments in shallow marine environments. GSA Bulletin, 86, 1244-1254.

Richter, R. \& Richter, E. 1939. Marken und Spuren aus allen Zeiten. III. Eine Lebens-Spur (Syncoprulus pharmaceus), gemeinsam dem rheinischen und böhmischen Ordovicium. Senckenbergiana, 21, 152-168.

Seilacher, A. 2007. Trace Fossil Analysis. Springer, Berlin, 226 pp.

Shen, C., Prett, B. R. \& Xhang, X.-G. 2014. Phosphatized coprolites from the middle Cambrian (Stage 5) Duyun fauna of China. Palaeogeography, Palaeoclimatology, Palaeoecology, 420, 104-112.

Shinn, E. A. 1968. Burrowing in recent lime sediments of Florida and the Bahamas. Journal of Paleontology, 42, 837-840.

Siir, S., Kallaste, T., Kiipli, T. \& Hints, R. 2015. Internal stratification of two thick Ordovician bentonites of
Estonia: deciphering primary magmatic, sedimentary, environmental and diagenetic signature. Estonian Journal of Earth Sciences, 64, 140-158.

Solan, M. \& Wigham, B. D. 2005. Biogenic particle reworking and bacterial-invertebrate interactions in marine sediments. In Interactions Between Macro- and Microorganisms in Marine Sediments (Kristensen, E., Haese, R. \& Kostka, J. E., eds), Coastal and Estuarine Studies, 60, 105124.

Stamhuis, E. J., Videler, J. J. \& Wilde, P. A. W. J. de. 1998. Optimal foraging in the thalassinidean shrimp Callianassa subterranean - improving food quality by grain size selection. Journal of Experimental Marine Biology and Ecology, 228, 197-208.

Sun, H.-J., Babcock, L. E., Peng, J. \& Zhao, Y.-L. 2014. Hyolithids and associated trace fossils from the Balang Formation (Cambrian Stage 4), Guizhou, China. Palaeoworld, 24, 55-60.

Tarhan, L. G., Hood, A. S., Droser, M. L., Gehling, J. G. \& Briggs, D. E. 2016. Exceptional preservation of softbodied Ediacara biota promoted by silica-rich oceans. Geology, 44, 951-954.

Toom, U., Vinn, O. \& Hints, O. 2017. A review of ichnofossils from Estonian palaeontological collections. In 10th Baltic Stratigraphical Conference. Chęciny 12-14 September 2017. Abstracts and Field Guide. Warszawa (Żylińska, A., ed.), pp. 83-84. Faculty of Geology, University of Warsaw.

Toom, U., Vinn, O. \& Hints, O. 2019a. Ordovician and Silurian ichnofossils from carbonate facies in Estonia: a collectionbased review. Palaeoworld, 28, 123-144.

Toom, U., Isakar, M., Hints, O., Madison, A. \& Vinn, O. 2019 b. Micro-coprolites inside Ordovician body fossils from Estonia. In 13th International Symposium on the Ordovician System: Contributions of International Symposium. Novosibirsk, Russia (July 19-22, 2019) (Obut, O. T., Sennikov, N. V. \& Kipriyanova, T. P., eds), pp. 211-214. Publishing House of SB RAS, Novosibirsk.

Torsvik, T. T. \& Cocks, L. R. M. 2013. New global palaeogeographical reconstructions for the Early Palaeozoic and their generation. Geological Society, London, Memoirs, 38, 5-24.

Uchman, A. 1995. Taxonomy and palaeoecology of flysch trace fossils: the Marnoso-arenacea Formation and associated facies (Miocene, Northern Apennines, Italy). Beringeria, 15, 3-115.

Uchman, A. 1999. Ichnology of the Rhenodanubian flysch (Lower Cretaceous-Eocene) in Austria and Germany. Beringeria, 25, 65-171.

Uchman, A., Hanken, N. M. \& Binns, R. 2005. Ordovician bathyal trace fossils from metasiliciclastics in Central Norway and their sedimentological and paleogeographical implications. Ichnos, 12, 105-133.

Uchman, A., Rodríguez-Tovar, F. J., Machaniec, E. \& Kedzierski, M. 2013. Ichnological characteristics of Late Cretaceous hemipelagic and pelagic sediments in a submarine high around the OAE-2 event: a case from the Rybie section, Polish Carpathians. Palaeogeography, Palaeoclimatology, Palaeoecology, 370, 222-231.

van Keulen, P. \& Rhebergen, F. 2017. Typology and fossil assemblage of Sandbian (Ordovician) 'baksteenkalk': an 
erratic silicified limestone of Baltic origin from the northeastern Netherlands and adjacent areas of Germany. Estonian Journal of Earth Sciences, 66, 198-219.

Vinn, O. \& Toom, U. 2016. Rare arthropod traces from the Ordovician and Silurian of Estonia (Baltica). Neues Jahrbuch für Geologie und Paläontologie, Abhandlungen, 280, 135-141.

Vinn, O., Wilson, M. A., Zatoń, M. \& Toom, U. 2014. The trace fossil Arachnostega in the Ordovician of Estonia (Baltica). Palaeontologia Electronica, 17.3.40A, 1-9.

Vinn, O., Wilson, M. A. \& Toom, U. 2015. Distribution of Conichnus and Amphorichnus in the early Paleozoic of Estonia (Baltica). Carnets de Géologie, 15, 269-278.

Vinn, O., Ernst, A., Toom, U. \& Isakar, M. 2018. Cryptic encrusting fauna inside invertebrate fossils from the Ordovician of Estonia. Annales Societatis Geologorum Poloniae, 88, 285-290.

Vizcaïno, D., Álvaro, J. J. \& Monceret, E. 2004. Trilobites and ichnofossils from a new fossil Lagerstätte in the Lower Cambrian Pardailhan Formation, southern Montagne Noire, France. Geobios, 37, 277-286.

Wanless, H. R., Burton, E. A. \& Dravis, J. 1981. Hydrodynamics of carbonate fecal pellets. Journal of Sedimentary Petrology, 51, 27-36.
Wilson, M. A. \& Palmer, T. J. 1992. Hardgrounds and hardground faunas. University of Wales, Aberystwyth, Institute of Earth Studies Publications, 9, 1-131.

Wotton, R. S. \& Malmqvist, B. 2001. Feces in Aquatic Ecosystems: Feeding animals transform organic matter into fecal pellets, which sink or are transported horizontally by currents; these fluxes relocate organic matter in aquatic ecosystems. BioScience, 51, 537544.

Wright, V. P. \& Cherns, L. 2016. How far did feedback between biodiversity and early diagenesis affect the nature of Early Palaeozoic sea floors? Palaeontology, 59, 753-765.

Zagora, I. 1997. Tiefwasser-Lehenspuren aus dem Ordovizium der Insel Rügen (NE Deutschland). Neues Jahrbuch für Geologie und Paläontologie. Abhandlungen, 203, 351368.

Zhang, X., Bergström, J., Bromley, R. G. \& Hou, X. 2007. Diminutive trace fossils in the Chengjiang Lagerstätte. Terra Nova, 19, 407-412.

Živković, S. \& Bogner, D. 2006. Coprolite status of Coptocampylodon lineolatus Elliott 1963 (incertae sedis) from Middle Eocene deep-sea sediments of Istria (Croatia). Micropaleontology, 52, 371-379.

\section{Mikrokoproliidid Eesti Ordoviitsiumi makrofossiilides}

\section{Ursula Toom, Olev Vinn, Mare Isakar, Anna Madison ja Olle Hints}

Fossiilsed ekskremendid ehk koproliidid on halvasti säilivad jäljekivistised, mis kannavad olulist paleoökoloogilist ja sedimentoloogilist teavet. Artiklis on kirjeldatud Eesti Kesk- ja Ülem-Ordoviitsiumist (Baltoskandia paleobassein) makrofossiilide kodade sisemuses säilinud mikrokoproliite ning nende levikut ja mitmekesisust. Uuritud materjal sisaldab üle 180 koproliite sisaldava makrofossiili, mis on kogutud enam kui 40 leiukohast ja esindavad mitmesuguseid madalaveelisi keskkondi alates jahedaveelisest karbonaatsest platvormist troopilise avašelfini. Stratigraafiliselt pärinevad mikrokoproliitide leiud Volhovi lademest kuni Pirgu lademeni (Dapingi kuni Kati globaallade). Mikrokoproliidid on ovaalsed või pulkjad, 0,1-1,8 mm pikkused ja 0,08-0,75 mm läbimõõduga; pikkuse/läbimõõdu suhe ulatub 6-ni. Mikrokoproliidid esinevad tigude, karpide, peajalgsete, käsijalgsete, okasnahksete ja trilobiitide kodades ning kuuluvad valdavalt liikidesse Coprulus oblongus ja Coprulus bacilliformis. Lisaks tuvastati kaks kompleks-jäljekivistist: Tubularina (koproliidid ümmarguse ristlōikega käikudes) ja Alcyonidiopsis (koproliidid lintjates käikudes). Mikrokoproliidid tekitati siis, kui organismide tühjad kojad asusid merepõhjas või olid veidi settesse mattunud. Koproliidid säilisid tõenäoliselt tänu kodade mehaanilisele kaitsele ja kiirele mineraliseerumisele. Mikrokoproliitide tekitajate bioloogiline päritolu jääb spekulatiivseks, kuid tõenäolisemate rühmade hulka kuuluvad polüheedid, kellel on sobiv suurus ja kehakuju ning kelle tänapäevased esindajad tekitavad ühesuguseid fekaale. Võimalik, et mikrokoproliitide tekitamisel osalesid erineva toitumisstrateegiaga organismid. Valitud leiukohtade makrofossiilide süstemaatiline uuring näitas, et kuni pooltes kodades esineb mikrokoproliite. See näitab koproliite tootvate organismide suurt arvukust ja mitmekesisust Baltoskandia Ordoviitsiumi basseinis. Meie materjal näitas ka, et Arachnostega jäljekivististe tekitaja ei olnud tõenäoliselt mikrokoproliitidega seotud. 